\title{
Amphitrite fauveli sp.n. (Polychaeta: Terebellidae) from the Bay of Biscay and the Gulf of Cadiz (NE Atlantic)
}

\author{
Igor A. Jirkov ${ }^{1}$, Ascensão Ravara², Marina R. Cunha² \\ ${ }^{I}$ Department of Hydrobiology, Biological faculty, Moscow State University, Moscow, Russia. e- \\ mail: ampharete@yandex.ru; corresponding author \\ ${ }^{2}$ Departamento de Biologia \& CESAM, Universidade de Aveiro, Portugal.e-mail: aravara@ua.pt, \\ marina.cunha@ua.pt
}

ABSTRACT: A new species of Amphitrite is described from two different regions in the NE Atlantic: the Bay of Biscay and the Gulf of Cadiz. Amphitrite fauveli sp.n. differs from other Amphitrite species with cirriform branchiae mainly by having a smaller number of nephridial papillae (four pairs) and by lacking eyespots. In the Bay of Biscay, the new species occurred on the slope of two submarine canyons - Saint Nazaire (1105 m depth) and the head of a Cap Breton canyon tributary (214 $\mathrm{m}$ depth), associated with coral framework (Madrepora oculata Linnaeus, 1758 and Lophelia pertusa (Linnaeus, 1758) in Saint Nazaire canyon, Dendrophyllia cornigera (Lamarck, 1816) in the Cap Breton tributary). In the Gulf of Cadiz the species was collected from the crater of two mud volcanoes (Darwin and Captain Arutyunov), at depths between 1100 and $1317 \mathrm{~m}$.

How to cite this article: Jirkov I.A., Ravara A., Cunha M.R. 2018. Amphitrite fauveli sp.n. (Polychaeta: Terebellidae) from the Bay of Biscay and the Gulf of Cadiz (NE Atlantic) // Invert. Zool. Vol.15. No.1. P.85-91. doi: 10.15298/invertzool.15.1.06

KEY WORDS: Annelida, taxonomy, slope, submarine canyons, mud volcanoes.

\section{Amphitrite fauveli sp.n. (Polychaeta: Terebellidae) из Бискайского и Кадисского заливов (Северо-Восточная Атлантика)}

\footnotetext{
И.А. Жирков ${ }^{1}$, А. Равара², М.Р. Кунха

${ }^{1}$ Кафедра гидробиологии, биологический факультет, Московский государствен-ный университет имени М.В. Ломоносова, Москва, Россия. е-таil: ampharete@yandex.ru; автор для переписки.

${ }^{2}$ Departamento de Biologia \& CESAM, Universidade de Aveiro, Portugal.e-mail: aravara@ua.pt, marina.cunha@ua.pt

РЕЗЮМЕ: Описан новый вид Amphitrite из двух районов Северо-Восточной Атлантики: Бискайского и Кадисского заливов. Amphitrite fauveli sp.n. отличается от других видов Amphitrite с усиковидными жабрами в основном меньшим числом нефридиальных папилл (четыре пары) и отсутствием глаз. В Бискайском заливе вид встречается на склонах двух подводных каньонов - Сен-Назер (на 1105 м) и в вершине притока каньона Кейп-Бретон (214 м), в ассоциации коралловых рифов (Madrepora oculata Linnaeus, 1758 и Lophelia pertusa (Linnaeus, 1758) в каньоне Сен-Назер и Dendrophyllia cornigera (Lamarck, 1816) в каньоне Кейп-Бретон). В Кадисском
} 
заливе вид собран в кратере двух иловых вулканов (Дарвин и Капитан Арутюнов), на глубине 1100-1317 м.

Как цитировать эту статью: Jirkov I.A., Ravara A., Cunha M.R. 2018. Amphitrite fauveli sp.n. (Polychaeta: Terebellidae) from the Bay of Biscay and the Gulf of Cadiz (NE Atlantic) // Invert. Zool. Vol.15. No.1. P.85-91. doi: 10.15298/invertzool.15.1.06

КЛЮЧЕВЫЕ СЛОВА: аннелиды, таксономия, материковый склон, подводные каньоны, иловые вулканы.

\section{Introduction}

Over the past 16 years, several cruises have taken place around the Iberian coasts (NE Atlantic) under the framework of various international deep-sea research programmes (e.g. UNESCO-IOC Training Through Research, HERMES, HERMIONE, CHEMECO). Within these projects about 50 terebellid polychaete specimens were collected from two submarine canyons in the Bay of Biscay (Saint Nazaire and Cap Breton) and six mud volcanoes and adjacent habitats in the Gulf of Cadiz. The family Terebellidae sensu lato (as defined by Hutchings et al., 2017) contains currently 72 genera and over 600 nominal species and includes a huge diversity of forms, most of them tubedwellers living attached to a hard substrate. Although the greatest variety of terebellids is observed in shallow waters, they can also be found in deep-waters (Rouse, Pleijel, 2001; Hutchings et al., 2017). In this study, seven terebellid genera were found within a depth range of 214 to $1317 \mathrm{~m}$ (six in the Gulf of Cadiz, two in the Bay of Biscay): Amphitrite Müller, 1771 (9 specimens of two species: one with cirriform branchiae, another with arborescent), cf. Axionice Malmgren, 1866 (1 specimen), Euthelepus McIntosh, 1885 (5 specimens), Nicolea Malmgren, 1866 (1 specimen), Pista Malmgren, 1866 (3 specimens), Polycirrus Grube, 1850 (9 specimens) and Thelepus Leuckart, 1849 (1 specimen), plus several undetermined specimens. Here we describe a new species of Amphitrite collected in samples from the Bay of Biscay and the Gulf of Cadiz.

There is some confusion in the use of Amphitrite and Neoamphitrite Hessle, 1917 names.
Some authors accept both genera as valid (Uschakov, 1955; Fauchald, 1977; Hartman, 1969; Holthe, 1986a,b; Hartmann-Schröder, 1996), some do not (Fauvel, 1927; Pettibone, 1956; Day, 1967; Hartmann-Schröder, 1971; Jirkov, 2001; Hutchings et al., 2017). The two genera differ only by the shape of branchiae: cirriform in Amphitrite and arborescent in Neoamphitrite. Hutchings et al. (2017) also accepted Neoamphitrite as junior synonym of Amphitrite and we share the same opinion. Read et al. (2016) listed 22 valid species of Amphitrite, but only three of them have cirriform branchiae: Amphitrite cirrata Müller, 1776, A. kerguelensis McIntosh, 1876 and A. oculata Hessle, 1917; the other 17 have arborescent branchiae; and two (Amphitrite luna Dalyell, 1853 and $A$. ramosa Risso, 1826) are indeterminable because of the very poor original descriptions. In our opinion Neoamphitrite should be accepted as a junior synonym of Amphitrite. The new species described here has cirriform branchiae and we limited its comparison with species of Amphitrite with cirriform branchiae.

\section{Material and methods}

The Amphitrite specimens were obtained from two NE Atlantic regions: the Bay of Biscay and the Gulf of Cadiz (Fig. 1, Table 1). In the Bay of Biscay two localities were sampled during the cruise M84-5 (RV METEOR) under the framework of the HERMIONE project, one at the Saint Nazaire canyon (1105 m depth) and another one at the head of a Cap Breton canyon tributary (214 m depth). These areas are characterised by the presence of the cold-water corals Lophelia pertusa (Linnaeus, 1758) and $\mathrm{Ma}$ - 


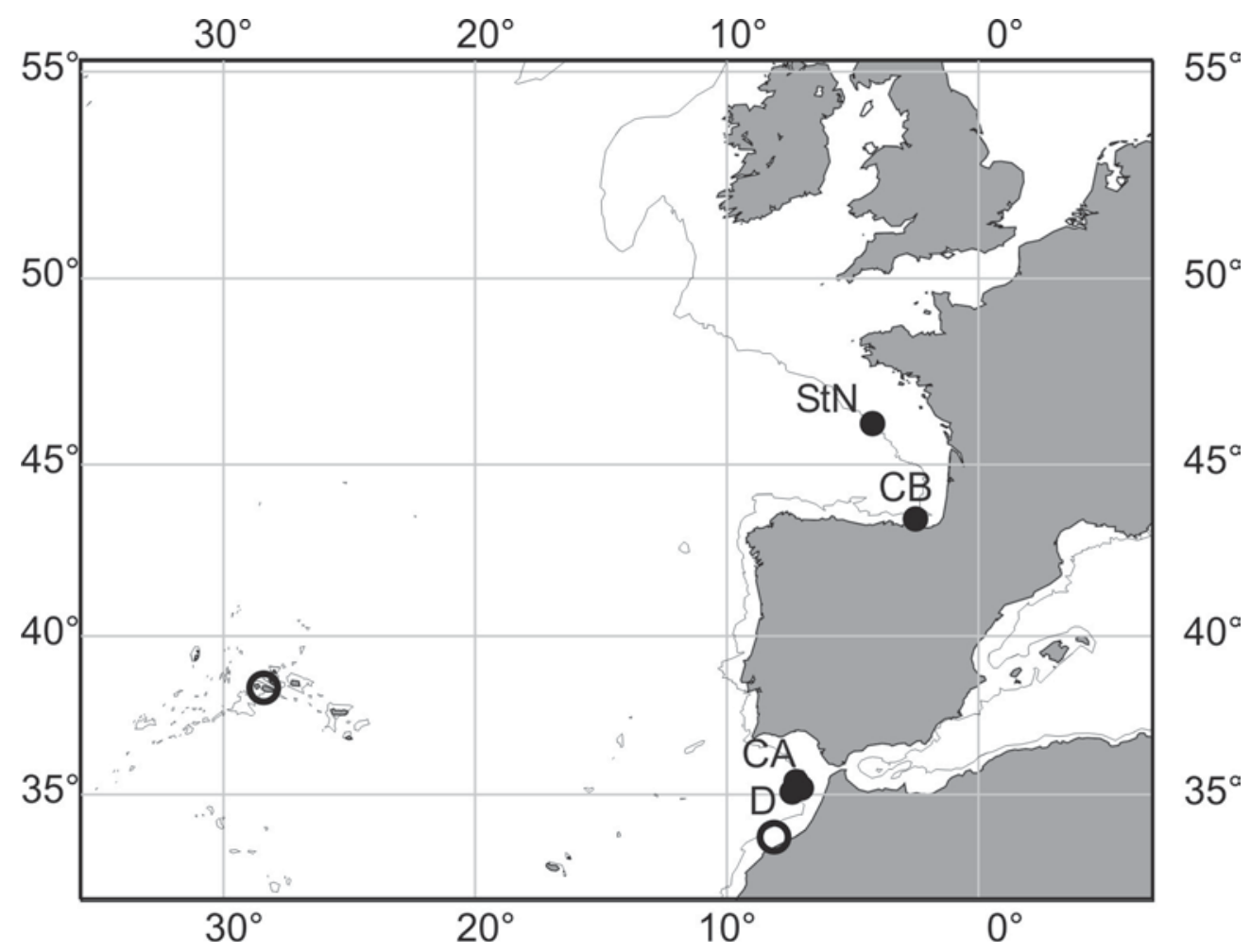

Fig. 1. Map with the location of the sampling sites (filled circles) and distribution of Amphitrite cirrata profunda (outlined circles). Abbreviations: CA - Captain Arutyunov MV; CB - head of Cap Breton canyon tributary; D - Darwin MV; StN - Saint Nazaire canyon. Isobath $1000 \mathrm{~m}$ is shown.

Рис. 1. Карта мест сбора проб (залитые круги) и распространение Amphitrite cirrata profunda (незалитые круги). Обозначения: CA - вулкан Капитан Арутюмов MV; CB - вершина притока каньона Кейп-Бретон; D — вулкан Дарвин; StN — каньон Сен-Назер. Показана изобата 1000 m.

Table 1. Metadata for the sampling stations in the Bay of Biscay and the Gulf of Cadiz. Station code: the label is composed of the cruise name and station number as used in Pangaea database (www.pangaea.de). Code of gear: BL - BIGO lander, CHE - colonization devices,

$\mathrm{Gr}$ - TV-assisted grab, UB - USNEL Boxcorer.

Таблица 1. Данные по станциям в Бискайском и Кадисском заливах. Код станции образован названием рейса и номером станции, использованном в базе данных Pangaea (www.pangaea.de).

Коды для орудий лова: $\mathrm{BL}$ - спускаемый аппарат BIGO, CHE - устройство для изучения колонизации древесины, $\mathrm{Gr}$ - управляемый по телевизору дночерпатель,

UB - USNEL Бокскорер.

\begin{tabular}{|c|c|c|c|c|c|c|}
\hline Structure & Station code & Gear & $\begin{array}{c}\text { Date } \\
\text { dd.mm.yy }\end{array}$ & Latitude & Longitude & $\begin{array}{c}\text { Depth } \\
\text { (m) }\end{array}$ \\
\hline \multicolumn{7}{|c|}{ Bay of Biscay - Submarine canyons } \\
\hline St. Nazaire & M84-5_649 & $\mathrm{UB}$ & 15.06 .11 & $46^{\circ} 13.98^{\prime} \mathrm{N}$ & $04^{\circ} 20.52^{\prime} \mathrm{W}$ & 1105 \\
Cap Breton & M84-5_677 & $\mathrm{Gr}$ & 17.06 .11 & $43^{\circ} 31.68^{\prime} \mathrm{N}$ & $02^{\circ} 45.48^{\prime} \mathrm{W}$ & 214 \\
\hline \multicolumn{7}{|c|}{ Gulf of Cadiz - Mud volcanoes } \\
\hline Darwin & B09/14b_02 & $\mathrm{CHE}$ & 19.05 .09 & $35^{\circ} 23.5233^{\prime} \mathrm{N}$ & $07^{\circ} 11.513^{\prime} \mathrm{W}$ & 1100 \\
Darwin & TTR16_AT608 & $\mathrm{Gr}$ & 30.05 .06 & $35^{\circ} 23.531^{\prime} \mathrm{N}$ & $07^{\circ} 11.475^{\prime} \mathrm{W}$ & 1115 \\
Captain & MSM01/3_212 & $\mathrm{BL}$ & 30.04 .06 & $35^{\circ} 39.681^{\prime} \mathrm{N}$ & $07^{\circ} 19.981^{\prime} \mathrm{W}$ & 1317 \\
Arutyunov & &
\end{tabular}


drepora oculata (Linnaeus, 1758) in Saint Nazaire canyon, and Dendrophyllia cornigera (Lamarck, 1816) in the Cap Breton tributary. In the Gulf of Cadiz, the Amphitrite specimens were sampled from the crater of two mud volcanoes (MV). On the Darwin MV one sample was taken during the cruise TTR16 (1115 m, RV Prof. Logachev, Training Through Research programme, IOC-UNESCO) and another one from a wood colonization experiment retrieved two years after deployment $(1100 \mathrm{~m}$, cruise B09-14b, RV Belgica, project CHEMECO). On the Captain Arutyunov MV one sample was taken during the cruise MSM01-03 (1317 m, RV Maria S. Merian, project HERMES). Metadata of the sampling sites are provided in Table 1 and the location of the mud volcanoes is shown in Figure 1. An account of the colonization experiments and a brief description of Darwin MV are provided by Cunha et al. (2013a). Details on the environmental setting of the Captain Arutyunov MV can be found in Cunha et al. (2013b).

Whenever possible the specimens were sorted on board and preserved in $96 \%$ ethanol. Photographs have been captured with a camera Canon EOS 1100D coupled to a stereomicroscope Leica M80 at Departamento de Biologia \& CESAM, Universidade de Aveiro and by camera Leica DFC425C camera mounted on a Leica DMI 5000B compound microscope at the Department of invertebrate zoology of Moscow State University, Moscow. In order to increase contrast, specimens have been stained by methylene blue (in water solution). The holotype was deposited in the Natural History Museum, London (NHM), and the remaining material was deposited in the Biological Research Collection, Departamento de Biologia, Universidade de Aveiro (DBUA).

\section{ABBREVIATIONS}

AU — abdominal segment with uncini, BS branchiferous segments, $\mathrm{C}$ - chaetiger, $\mathrm{S}$ segment, TC - thoracic chaetiger, TU - thoracic segment with uncini; the number following the abbreviation refers to the number of the segment, for example BS1 means the $1^{\text {st }}$ branchiferous segment.

\section{Systematics}

Class POLYCHAETA Grube, 1850 Order TEREBELLOMORPHA Hatschek, 1893

Family TEREBELLIDAE Malmgren, 1866 Amphitrite Müller, 1771

= Neoamphitrite Hessle, 1917

Type species: Amphitrite cirrata Müller, 1771.

DIAGNOSIS. Three pairs of branchia on S2, S3 and S4. Lateral lobes small. Notopodia present from S4, notochaetae of two types: long and smooth, bilimbate and short, geniculated with serrated tips. Uncini avicular without manubrium, from C8 in double rows (double rows neuropodia) at least to the end of thorax.

\section{Amphitrite fauveli sp.n.}

Figs 2-4.

Material examined. Atlantic Ocean. Bay of Biscay. Tributary of Cap Breton canyon, St M84-5 677, 214 m, 1 large specimen (NHM ANEA 2017.194, Holotype); Saint Nazaire canyon, St M84-5 649, 1105 m, 1 specimen (DBUA0001973). Gulf of Cadiz: Darwin MV, St B09-14b_02W, $1100 \mathrm{~m}, 1$ gravid female (DBUA0001953); St TTR16_AT608, 1115 m, 1 specimen without branchae on one side (DBUA0001962); Captain Arutynov MV, St MSM01/3_212, $1317 \mathrm{~m}, 1$ small specimen (DBUA0001963).

DESCRIPTION (based on holotype and paratypes). Length up to $80 \mathrm{~mm}, 5 \mathrm{~mm}$ width, near $100 \mathrm{~S}$. Buccal tentacles short, near $1 / 5$ of body length. Eyespots absent. Branchiae consisting of numerous cirriform filaments attached directly to short thick symmetric wart like stem, which is small in the smaller worms and larger in holotype (Fig. 2C). Number of filaments in the holotype: BS $1-15, \mathrm{BS} 2-10, \mathrm{BS} 3-8$. Specimen from St MSM01/3_212 has no branchia on the left side of S1 and on the right side of S3; no scars were found. S1 forms a small lower lip (Fig. 2E, F). Lobes of S2-S4 distinct (Fig. 2F, G): S2 - low, lateral dorsal margin 


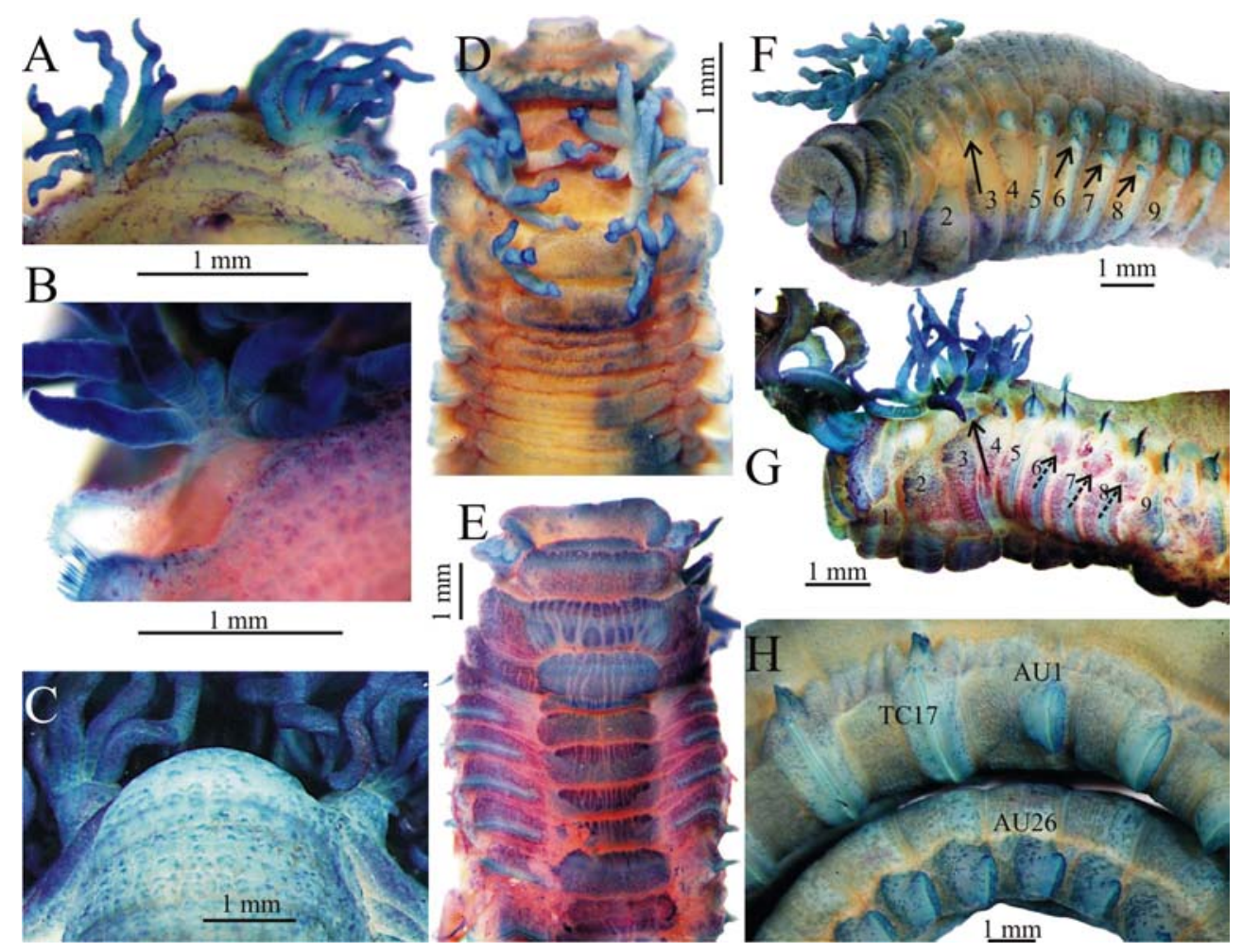

Fig. 2. Amphitrite fauveli sp.n., external morphology. A-C - dorsal views showing BS3 branchiae; D dorsal view of anterior part; $\mathrm{E}$ - ventral view of anterior part; F, G - lateral view of anterior part (F - all left branchiae removed); $\mathrm{H}$ - details of posterior thorax and some AU.

A, F — DBUA0001963; B, E, G — DBUA0001953; C, H - holotype, NHM ANEA 2017.194; D — DBUA0001973. F-H: numbers refer to segment number; F, G - solid arrows point to nephridial papillae, $\mathrm{G}$ - dotted arrow point to inflated shields replaced papillae.

Pис. 2. Amphitrite fauveli sp.n., внешняя морфология. А-C - вид со спины, показывающий жабры $\mathrm{BS3}$; D — вид со спины передней части тела; Е — то же, вентральный вид; F, G — то же, вид сбоку (F - все левые жабры удалены); H - детальное строение задней части торакса и некоторых AU. Abbreviations: A, F — DBUA0001963; B, E, G — DBUA0001953; C, H — голотип, NHM ANEA 2017.194; D — DBUA0001973. F-H: цифры означают номера сегментов; F, G - сплошные стрелки указывают на нефридиальные папиллы, $\mathrm{G}$ - пунктирные стрелки указывают на вздутые поля, замещающие нефридиальные папиллы.

higher and disappearing ventrally; S3 - semicircular reaching the upper margin of first uncinigerous row, $\mathrm{S} 4$ - smaller and more dorsal, slowly disappearing ventrally. 17 TC. Ventral pads until C10, smooth (Fig. 2E). Notochaetae long and smooth, bilimbate and short, geniculated with serrated tips (Fig. 3). Uncini avicular from $\mathrm{C} 2$ facing forward, similar in thorax (Fig. 4A) and abdomen (Fig. 4B), but the thoracic ones slightly larger and with a more developed heel. On C8-C17 the uncini are in double rows, face-to-face, with rows well apart (Fig. 4C). All abdominal uncini in single rows facing forward. Thoracic unicinigerous rows large, the nine anterior almost reaching the ventral pads (Fig. $2 \mathrm{E})$. Length of the uncinigerous row of TU1 slightly smaller than TU2, but in all anterior neuropodia equal to or larger than the width of the widest ventral pad. All thoracic neuropodia are tori (transversal cushion, uncini are situated in a medial furrow Fig. 2H TC17), abdominal neuropodia gradually transformed into fan-like 


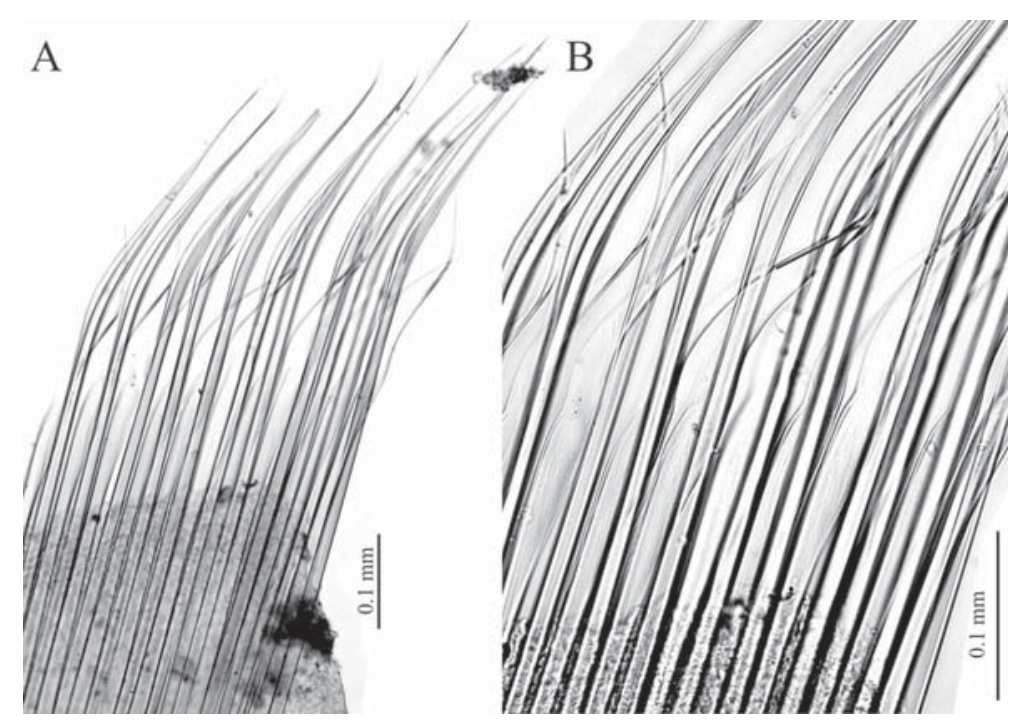

Fig. 3. Amphitrite fauveli sp.n., notochaetae of TC11 (DBUA0001953).

Рис. 3. Amphitrite fauveli sp.n., нотохеты TC11 (DBUA0001953).

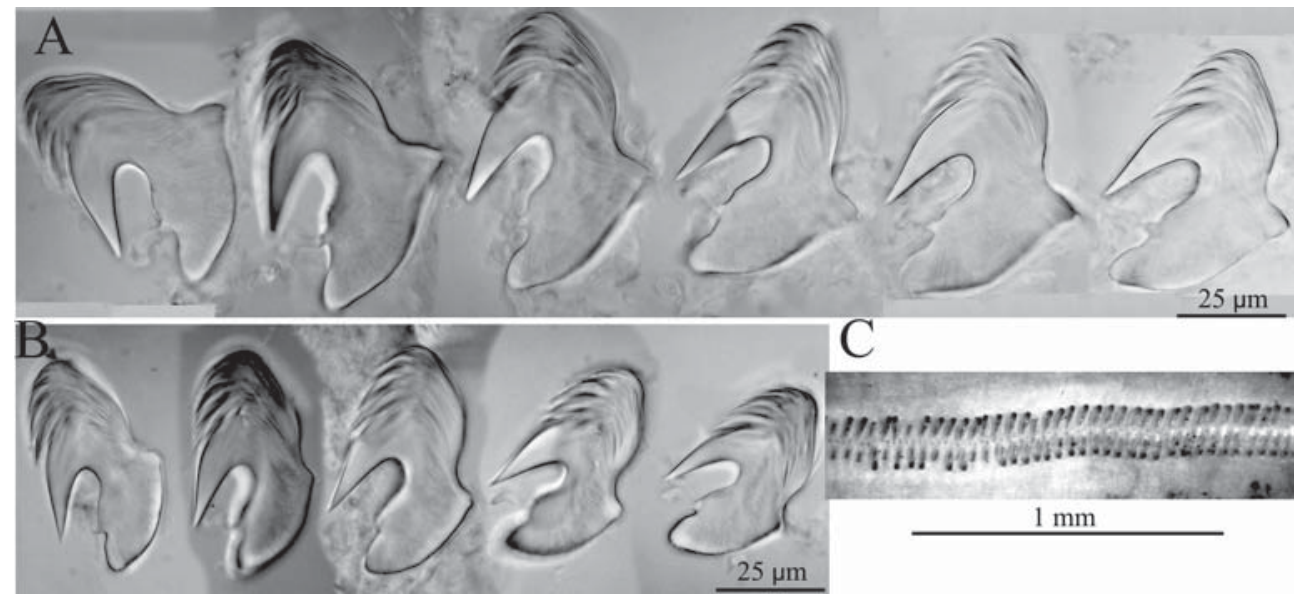

Fig. 4. Amphitrite fauveli sp.n., uncini. A - TU1; B - AU29; C - double row. A, B - DBUA0001953; C - holotype, NHM ANEA 2017.194.

Pис. 4. Amphitrite fauveli sp.n., неврохеты. А - TU1; В - AU29; C - двойной ряд. A, В DBUA0001953; C — голотип, NHM ANEA 2017.194.

rectangular pinnules posteriorly (Fig. $2 \mathrm{H}$ AU1, AU26), but uncini are not situated at the margin as it is in pinnuli of Ampharetidae. Uncinigerous row of AU1 half the length of the row from last TU. A pair of nephridial papillae present in S3 (BS2) laterally to branchiae, very large, almost half the size of notopodia of TC1 (BS3); absent in S4 and S5; present again between notopodia and neuropodia of S6-S8, much small- er than in S3 (Fig. 2F). The gravid female presents inflated shields instead of papillae in S6-S8, papillae of S3 normally developed (Fig. $2 \mathrm{G})$. Pygidium with crenulated margins, without papillae.

DIFFERENTIAL DIAGNOSIS. Three species of Amphitrite have cirriform branchia. The new species differs from two of them by the smaller number of nephridial papillae ( 8 in $A$. 
cirrata, 7 in A. kerguelensis, 4 in A. fauveli sp.n.). The third species $A$. oculata from Japan and Australia has also four segments with nephridial papillae but it has eyespots, absent in A. fauveli sp.n.

REMARKS. A. cirrata profunda Fauvel, 1909 was recorded from off the Azores and Morocco at depths between 778-1287 $\mathrm{m}$ and probably is the same species as described here. However, according to the International Code of Zoological Nomenclature (ICZN, 1999), A. cirrata profunda should be interpreted as nomen nudum as it fails to conform to Article 12 (Article 12.1: "To be available, every new name published before $1931 \ldots$ must be accompanied by a description or a definition of the taxon that it denotes"). The only sentence describing this taxon is "Ils sont principalement caractérisés par le petit nombre et la forme relativement trapue de leurs filets branchiaux" (Fauvel, 1909: 26) which can not be interpreted as a description or definition of a taxon. The number of cirri of the single branchia depends on the size of worm, while the shape of cirri depends on degree of relaxation during fixation. Thus none of the characters mentioned by Fauvel (1909) allow us to distinguish this taxon from the ones previously known. Furthermore, Solís-Weiss et al. (2004) did not list Fauvel's material in the collection of the Muséum national d'Histoire naturelle, Paris where to all alcohol-preserved specimens were transferred. So there is no other way than to describe the new species.

ETYMOLOGY. The species is named after Prof. P. Fauvel who reported A. cirrata profun$d a$, a probable synonym of the new species.

\section{Acknowledgements}

Thanks are due to the chief-scientists, scientific parties and crews of the cruises TTR16 (RV Prof. Logatchev, Training Through Research Programme, IOC-UNESCO), MSM01-03 (RV Maria S Merian), and B09-14b (RV Belgica).

This work was supported by CESAM (UID/ $\mathrm{AMB} / 50017 / 2013$ ) financed by $\mathrm{FCT} / \mathrm{MEC}$ through national funds and co-funded by the FEDER within the PT2020 Partnership Agreement and Compete 2020, by EURODEEP/0001/ 2007 (project CHEMECO, ESF EuroDEEP pro- gramme), by the European Commission Sixth Framework Programme (FP6) under the HERMES project (EC contract GOCE-CT-511234), and by Seventh Framework Programme (FP7) under the HERMIONE project (EC contract 226354). The first author was supported by the Fauna Ibérica project (Fauna Ibérica XI: Polychaeta VI: Palpata-Canalipalpata I, CGL201453332-C5-3-P) and by the Russian Science Foundation (grant number 14-50-00029) for investigation within Russia. The second author was supported by a postdoctoral grant (SFRH/BPD/ 112408/2015) from FCT co-financed by ESF.

\section{References}

Cunha M.R., Matos F.L., Génio L., Hilário A., Moura C.J., Ravara A., Rodrigues C.F. 2013a. Are organic falls bridging reduced environments in the deep sea? Results from colonization experiments in the Gulf of Cádiz // PLOS One. Vol.8(10). e76688. doi: 10.1371/ journal.pone.0076688

Cunha M.R., Rodrigues C., Génio L., Hilário A., Ravara A., Pfannkuche O. 2013b. Macrofaunal assemblages from mud volcanoes in the Gulf of Cadiz: abundance, biodiversity partioning across spatial scales // Biogeosciences. Vol.10. P.2553-2568. doi:10.5194/bg-102553-2013.

Fauvel P. 1909. Deuxième note préliminaire sur les polychètes provenant des campagnes de l'Hirondelle et de la Princesse-Alice, ou déposées dans la Musée Océanographique de Monaco // Bulletin de l'Institute Océanographique de Monaco. Vol.142. P.1-76.

Hutchings P., Nogueira J.M.d.M., Carrerete O. 2017. Terebellidae s.1: Polycirridae Malmgren, 1866, Terebellidae Johnston, 1846, Thelepodidae Hessle, 1917, Trichobranchidae Malmgren, 1866, and Telothelepodidae Nogueira, Fitzhugh, Hutchings, 2013 // R.G. Schmidt-Rhaesa, M. Glaubrecht, N.P. Kristensen, L. Prendini, G. Purschke, S. Richter, W. Westheide, R. Leschen. Handbook of zoology online. A natural history of the phyla of the animal kingdom. Annelida: Polychaetes. De Gruyter. 64 p. https://www.degruyter. com/view/zoology/bp_029147-6_68

ICZN. 1999. International Code of Zoological Nomenclature. Fourth edition. The International Trust for Zoological Nomenclature 1999. http:/www.nhm.ac.uk/ hosted-sites/iczn/code/

Read G., Londoño Mesa M.H., Bellan G. 2017. Amphitrite Müller, 1771 // G. Read, K. Fauchald (ed.). World Polychaeta database. Accessed through: World Register of Marine Species at http://www.marinespecies.org/ aphia.php? $\mathrm{p}=$ taxdetails\&id=129686 on 2017-07-18.

Rouse G.W., Pleijel F. 2001. Polychaetes. Oxford: Oxford University Press. 354 p.

Solís-Weiss V., Bertrand Y., Helléouet M.-N., Pleijel F. 2004. Types of polychaetous annelids at the Muséum national d'Histoire naturelle, Paris // Zoosystema. Vol.26. No.3. P.377-384.

Responsible editor T.A. Britaev 